\title{
Creative and Problem Solving Thinking of Gifted and Talented Young Children Observed Through Classroom Dialogues
}

\author{
Ya-Chi Wang ${ }^{1}$, Ching-Chih Kuo ${ }^{1, *}$, Shu-Min Wu ${ }^{2}$ \\ ${ }^{1}$ Department of Special Education, National Taiwan Normal University, Taiwan \\ ${ }^{2}$ Department of Special Education, University of Taipei, Taiwan
}

Received September 18, 2019; Revised October 23, 2019; Accepted November 1, 2019

\begin{abstract}
Copyright $\odot 2019$ by authors, all rights reserved. Authors agree that this article remains permanently open access under
\end{abstract} the terms of the Creative Commons Attribution License 4.0 International License

\begin{abstract}
The preschool period is one of fast growth for a child's mental capacity and a key developmental period for their language, motion, and social interaction capabilities. Understanding children's learning characteristics helps us facilitate development of cognition for every child. In this study, we examined the creative and problem solving thinking of 8 young science talented children aged 4 to 6 through the dialogues and archives/ artworks in the classroom. Through this study, we hope to gain a better understanding of the characteristics of gifted young learners. The participated students in our study have attended an extra-curricular enrichment program with 2 hours of science class time per week for a total of 72 hours in one school year. The dialogues and archives/ artworks were collected from six units of science learning activities. All the oral data were videotape recorded, transcribed, validated, and coded by the researchers. The results showed that as compared to similar-age children, the participated children possessed keen observation ability and a wider general knowledge. They also exhibited superior verbal expressive, logical reasoning, elaborative, creative and flexible problem solving skills. In addition, the children were highly humorous and imaginative. Judging from the dialogues and performances, we believed that the earlier talented children are provided with appropriate programs and interaction with peers, the better their chances of fully actualizing their potential and enhancing higher order thinking skills.
\end{abstract}

Keywords Gifted, Talented, Young Children, Creativity, Problem Solving, Characteristics, Classroom Dialogues

\section{Introduction}

\subsection{General Characteristics of Gifted and Talented Children}

Due to the advanced cognitive development and superior cognitive ability, the way of thinking and feeling of gifted and talented young children are different from their typically developing peers. Many reports mentioned they are extremely curious about how things work; they show good memory; learn ideas quickly and can use them in new situations; can maintain attention for long periods of time on things that interest them; understand cause and effect; have lots of ideas and solutions for problems; use a greater variety of words and phrases than other children of the same age; communicating proficiently quickly; understand jokes and riddles; performing in deal with time concept; having higher problem-solving abilities; tries again and again and make efforts to find the solution; being full of original ideas. Besides, they have a strong sense of right and wrong; have intensely emotion; be sensitive to the emotions of others, and etc. [11,26,27,35,40,53,54].

Robinson [53] pointed out that gifted and talented children usually perform at age levels that are $1 / 4$ to $1 / 2$ beyond their actual age. For example, a 4-year-old child can at least perform at the level of a 5-year-old. Some children, on the other hand, performed at 2 or more age/grade categories beyond their peers [22]. Gifted and talented children at four or five are able to create complicated sentences and faster responses to questions asked by teachers; however, it is still important for teachers to scaffold them to express divergent thought and to find creative solutions during problem solving work and elevating their thinking skills [37]. 


\subsection{The Need of Facilitating Cognitive Development of Gifted and Talented Preschoolers}

Cognitive development occurring between ages 2 to 7 was considered the preoperational stage, according to Piaget and his Cognitive Developmental Theory [51]. The cognitive characteristics at preoperational stage include lack of logical reasoning and lack of logic-related concepts, such as category, sequence, and causal relationship. Ginsburg and Opper [19] pointed out that in general, children in the Preoperational Stage possess characteristics such as being self-centered, incapable of reverse thinking, and incapable of object conservation; they also pay attention to only passive but not active transformational processes. Bruner [4] rebutted against Piaget's Developmental Theory, however, and argued that cognitive development can be made using scaffolding, that teaching does not have to wait for developmental maturity. "Cognitive growth involves an interaction between basic human capabilities and culturally invented technologies that serve as amplifiers of these capabilities." (p.19) [4].

Feldman [16], a well-known human development scholar, felt that Piaget's cognitive development sequence was not suitable for highly gifted children. Cohen [9] also agreed that some children begin to show strong preferences for certain areas very early that their special interests in particular stimuli, symbolic system, social or environmental context at an early stage are strong indicators of advanced abilities. These special interests enabled children to perform better in specific domain or interest areas, such as music, chess, or mathematics. The children were able to competently use their cognitive abilities, such as memory, understanding, analysis, reasoning, and application; they also did not find it difficult to transfer learning in that specific domain or interest area $[14,33,3,42]$.

A fair amount of research has been done between the 1960's and 1980's on stage development of gifted children [10]. General finding indicated that there is faster movement within a stage among intellectually gifted children than their typically developing peers $[7,29,38]$. Kanevsky [32] used dynamic assessment to investigate strategy use and metacognition in four groups of preschool children: 4-and 5-year-old average and high IQ children and 7-and 8-year-old average and high IQ children. The two groups of young children who are gifted were more efficient in their strategy management than their age-mates. The young gifted children were also critical, insightful and able to switch between different strategies easier and faster before the instructor did the demonstration. Following a review of relevant researches, Cohen and Kim [10] noted that the young gifted children may not develop faster than their non-gifted counterparts, but the quality and breadth of ability within stage are evident. Haensly [24] also reported on two gifted preschoolers of $21 / 2$ years and 3 years 7 months respectively whose performance were significantly brighter than their peers, and found that they used a highly verbal monitoring strategy, demonstrated advanced understanding about concepts, and possessed superior causal inference and reasoning abilities. Nellis and Gridley [48] investigated the ability-related differences in problem-solving skills on a sociocultural task; there was no significant difference in planning skill between the high-ability preschoolers and peers of different ability, but the high ability preschoolers showed mature distribution of strategy choices and effective strategies in planning. They also performed equally well when working alone and when working with peers of sane ability. Additionally, Scott and Delgado [56] found that the gifted young children performed significantly better in unstructured semantic information and structured information than the non-gifted sample.

In this study, the researchers were interested specifically in the creative and problem solving characteristics of participating young children. In view of this, every class was videotape recorded so that the researchers were able to analyze videotape recording of classroom interaction and dialogues as well as examine the children's thinking characteristics. Asking questions, posing challenges, phrasing comments and modeling correct scientific terminology using may equip children with essential tools for building up their understanding. Those strategies also encourage children to observe more closely at the phenomena and begin to develop their scientific ideas about what might actually be happening [6].

\subsection{Classroom Dialogues and Learning}

Researchers have indicated that a key ingredient of high quality early childhood programs is teacher-child interaction [36]. Classroom dialogues are often discussed as a process of shared inquiry and help construction of knowledge collaboratively [43]. Making sense plays a crucial role in classroom learning; it is a social process, an activity firmly entrenched in social and historical settings [5]. When the child is able to how to use language in social situations and achieve with the scaffolding of adults or peers, not only will the child better building his/her understanding of the language, but he/she will also negotiate meaning and interpret what is going on, and at the same time reproduce the meanings and concepts of the child through language. As Vygotsky early told us, learning through interactions with adults or peers could stimulate higher levels of the child's cognitive abilities and internalizing behavior.

In learning process, the interaction with teachers or peers in a classroom, as part of the classroom dialogue, could challenge and enhance children cognitive engagement.-Providing more dialectics within interactions and relationships with others helped a child grasp the specific meanings that symbols convey or contain. When children learn languages, they use effective processing abilities that include hypothesis, testing, proving, disproving, and correcting to understand spoken and 
written speech, a process quite similar to how children learn science [55]. Moreover, they can be effective cognitive models for their peers by verbalizing their problem-solving strategies and methods of deductive reasoning [1]. Wegerif [61] offered evidence that a dialogic theory of learning to think can offer new and valuable insights into classroom interaction with the potential to inform pedagogy. Siry, Ziegler, and Max [57], through their multi-stage, multi-form research, proved that children aged 5-6 years were able to develop complex and insightful understandings of scientific concepts through conversational interaction.

\subsection{Analyzing Children's Creative and Problem Solving Characteristics from Archives}

Many young gifted and talented children can not only read early but also show precocity of competency and mastery without having explicitly taught. Through collecting and analyzing young gifted children' formal and informal narratives, Margrain [41] concluded their characteristics included questioning, demonstrating knowledge, creativity, memorization, inquiry and intense observation.

Although language can change children's concepts and enhance language development, sometimes children, due to limited expressive abilities, cannot clearly and coherently explain themselves in words. In addition to language, Harlen [25] suggested several ways to gain access children`s ideas, for example: questioning and discussing, studying non-written products, and asking for drawing and writing. Bruner [4] believed that knowledge and skill can be expressed through action, images, or symbols. Individuals first express themselves using action, and then as they develop the ability to express themselves using images, e.g. through drawings, and finally, they use linguistic symbols to represent knowledge.

In early childhood, drawing is a creative activity that fantasizes, consolidates and recreates visual experiences. Through their drawings and clay works, children display their mental imageries and thinking and communicate with others what's on their mind. Goodnow [21] figured out that it was important to collect children's drawings and conduct a thorough systematic evaluation, and that by listening to how children describe their work during the creative process, one can gain an understanding of their states of mental development. "Drawing" allows children to not only learn language, but also go through problem solving processes [17], and for a child, the problem solving process is the science learning process. Goodenough [20] pointed out that a child's drawing can be used to mark the child's mental or conceptual maturity. He developed the Draw-a-Man Test to evaluate children's mental capacities and found that children's drawings corresponded better to their mental age than their chronological age, that one can evaluate children's mental capacities through their drawings, through clarity of subject and level of detail.

The aforementioned descriptions indicate that one can gain an understanding of a child's creative and problem solving abilities through observing the child's verbal interactions, performance, drawings, and so on. 3-5 years-old is a time of rapid change for children to develop perceptional and conceptual perspective. Although type of asking questions is in a similar sequence as typical children, the content is different, gifted children may pick out unfamiliar words rather than ask for the identity of the object, because they are interested in abstract topics beyond here and now. [28]. Wolfe [63] derived data from a four-week summer school for gifted and talented young children. Some of them showed the ability to utilize their own reserve of knowledge, intellectual ability, and varied experiences to rationalize their observations

Kim [33] conducted a quantitative synthesis of correlations between IQ and creativity test scores. She concluded that IQ scores were more closely associated with creativity scores for younger groups than for older groups, for less educational influence on students' use of their cognitive abilities for younger groups compared with older groups. O'Brien [49] emphasized that creativity is the very essence, the joy, of doing science for more able pupils. Hou's study [31] provided further evidence that preschoolers' flow experiences have the effect of mediating between their gifted traits and scientific creativity. Bayanova's study [2] confirmed that children with high creativity have less degree of compliance with culture rules by analyzing 5-6-year-old children's behaviors based on parents' expert evaluation compared to children's drawings.

A study by Daglioglu, Çalisandemır, Alemdar., \& Bencik Kangal [12], in which the drawing process and characteristics of 4-5-year-old children with normal development and gifted children have been analyzed, showed that in both age groups gifted children, especially girls, drew more developed and detailed drawings.

This research collected data and analyze them qualitatively. We expect to gain a deeper understanding of gifted children's thinking traits which focused on creative and problem solving ability through their student-teacher in-class dialogues and performances, and develop more differential instruction for them.

\section{Research Method}

\subsection{Participants}

The participants in this research were 10 gifted and talented preschoolers aged 5 to 6 who were identified and recommended by their teachers to attend an enrichment program. These participants were selected when they scored higher than the $93^{\text {rd }}$ percentile on PIQ, VIQ, or FIQ on the Chinese version of the Wechsler Preschool and Primary Scale of Intelligence, Revised Edition (WPPSI-R) 
[8]. A series of observations on the performance of the preschoolers participating in the designed courses (observation activities) were involved in the identification. Considering the limitations of the use of standardized tests, especially for young children [22, 28, 52], the young children's portfolio provided by special talents were also used to determine eligibility for the gifted and talented program.

Table 1. The traits of 8 children observed through observation activities

\begin{tabular}{|c|c|c|c|c|c|c|}
\hline \multirow{2}{*}{ Code } & \multirow{2}{*}{ Sex } & \multirow{2}{*}{ Age } & \multicolumn{3}{|c|}{ WPPSI-R } & \multirow{2}{*}{ Personal traits observed through Natural Science activities } \\
\hline & & & PIQ & VIQ & FIQ & \\
\hline FB1 & M & $5-11$ & 134 & 89 & 112 & $\begin{array}{l}\text { This is a boy with mild Autism Spectrum Disorder, with excellent reasoning ability but low } \\
\text { expression levels of language. He presented concepts through operations. He was very good } \\
\text { at scientific concepts and causal inference. When he was interested with the subject of the } \\
\text { course, he showed highly concentrating at the content and pay attention to the details of the } \\
\text { picture. }\end{array}$ \\
\hline FB2 & M & $6-02$ & 111 & 131 & 125 & $\begin{array}{l}\text { This is an ADHD boy. He showed sensitive, clear expression, fast reading, ability to identify } \\
\text { common fruit names, and more knowledge about fruits (e.g. fruit fly) than peers. He couldn't } \\
\text { sit still during activities; he was very impulsive and blurt out the answer without carefully } \\
\text { thinking. He was good at using a magnifying glass to observed fruits. }\end{array}$ \\
\hline SB3 & M & $5-05$ & 129 & 149 & 144 & $\begin{array}{l}\text { This boy is good at using clear verbal communication techniques and organization of story } \\
\text { recall. His logical reasoning ability was excellent, and also excellent in performing deductive } \\
\text { or inductive reasoning. Fruits could be described by using adjectives, i.e. lychee is just like a } \\
\text { round cannon. His learning motivation was high and very focused on tasks. During the course } \\
\text { topics he liked, he showed excited by standing up, dancing, and active in expressing his ideas. }\end{array}$ \\
\hline SB4 & M & $6-01$ & 131 & 129 & 134 & $\begin{array}{l}\text { This boy suffered from ADHD but he made good use of multi-material materials. His art } \\
\text { works showed rich knowledge and creativity, and intertwined with imagination and science } \\
\text { knowledge. He had observational skills but due to his impulsive behavior problems, teachers } \\
\text { needed to adopt reinforcing strategies to improve his attention in the classroom. }\end{array}$ \\
\hline SB5 & M & $5-04$ & 131 & 124 & 130 & $\begin{array}{l}\text { The boy was able to tell the story fast and fluently, describe the fruit in a rich vocabulary, } \\
\text { such as banana as moon, lemon as a gyro, cantaloupe as sun. He showed the adhere traits to } \\
\text { creation, extremely focused until the work was completed. }\end{array}$ \\
\hline SB6 & M & 6-01 & 136 & 134 & 139 & $\begin{array}{l}\text { The boy's natural knowledge is rich; creative works were mostly done in comics with plots, } \\
\text { characters, and time and space. With complete comic techniques, the plot was imaginative, } \\
\text { rich and complete. He showed very stable emotion and with long-term maintenance of high } \\
\text { learning motivation. His abilities of observation, comparison, measuring, and logical } \\
\text { thinking were excellent. He always answered the questions after careful thinking, and then } \\
\text { explained the process dedicate. During the fruit observation activity, he carefully observed } \\
\text { the color and shape of the fruit; he was able to use thorny, shape and taste as the } \\
\text { classification criteria of fruits. }\end{array}$ \\
\hline SG7 & $\mathrm{F}$ & $5-02$ & 116 & 141 & 133 & $\begin{array}{l}\text { The girl's expression ability was good; the sentence was complete; the story was written in } \\
\text { a rich vocabulary, and the conclusion could be made for the story; the knowledge was rich; } \\
\text { the creation results were presented in a single concept. She also had strong motivation for } \\
\text { self-management in learning; self-discipline and strong sense of morality. She asked the } \\
\text { peers to behave in a discipline and learn the strengths of others. In a word, this girl was } \\
\text { confident and self-control. The fruits were classified by the shape after slicing; the color of } \\
\text { the pedicle; the seeds, colors and shapes in the fruit. }\end{array}$ \\
\hline SG8 & $\mathrm{F}$ & 6-01 & 117 & 128 & 127 & $\begin{array}{l}\text { The girl looked closely at the picture, plus "location", and "status". For example, she could } \\
\text { describe a picture with detailed information such as at the beach, wearing glasses. She was } \\
\text { shy during the observation course in natural science. Most of time, she sat and listened } \\
\text { quietly. She looked more active in group activity. She observed fruits with the sense of } \\
\text { smell and touch, and noticed the unevenness of the surface of the fruit, such as: the texture } \\
\text { of the melon; classify the fruit by quantity, shape and pedicle. }\end{array}$ \\
\hline FB9 & $\mathrm{M}$ & $4-11$ & 149 & 129 & 143 & $\begin{array}{l}\text { The boy was actively engaged in the activities and assignments in his exploration of } \\
\text { content. The instructions of teacher could be clearly remembered and followed. His } \\
\text { concentration was strong and the motivation was extremely high. He smelled the taste of the } \\
\text { fruit one by one and did a very good job at classification of the fruits. High creativity was } \\
\text { also seen in his language use with precise and refined words. Although he was only four } \\
\text { years old, he earned the highest recommendation rank among the peers. }\end{array}$ \\
\hline SB10 & $\mathrm{M}$ & $5-11$ & 143 & 125 & 136 & $\begin{array}{l}\text { The boy was very active; he showed very high motivation in classification activity. He } \\
\text { listened to the teacher's instructions, questions carefully and answered the questions very } \\
\text { fast. He was full of imagination, was able to integrate himself with the environment. He } \\
\text { showed confidence and had unique ideas. In a word, this boy was creative and active, and } \\
\text { continued asking questions during the activity. }\end{array}$ \\
\hline
\end{tabular}


The IQ test scores and traits observed through the Natural Science activities are presented in Table 1. Among the eight young children, 6 of them were more than two standard deviations above the mean $(M=100$, $S D=15$ ) (IQ 130) or scored in the $97^{\text {th }}$ percentile or more (IQ 127). Two young children suffered from mild autism or attention-deficit/hyperactivity disorder (ADHD). The two children attained full IQ below 130 but they exhibited superior performance on PIQ or VIQ over 130. They performed very well when engaged in the observation activities and thus, were recommended by teachers to attend this enrichment program.

During the Natural Science activities, the young children were asked to recognize fruits, observe fruits, and classify fruits. The assessment indicators include observation of interest and curiosity, fruit names identification, ability to use tools, ability to express words, ability to express thoughts or feelings, ability to use facial expressions to identify emotional states, ability to connect with festivals and seasons, different classification techniques, and attitudes about participation in the activities.

Only the children who were recommended by teachers and identified as talented in natural science were able to attend the enrichment program. A numbering scheme based on the child's age of enrollment, sex, and the child's serial number is shown in Table 2.

Table 2. Child Coding Reference

\begin{tabular}{|c|c|c|}
\hline Coding & $\begin{array}{c}\text { Symbolic } \\
\text { Content }\end{array}$ & Symbolic Meaning \\
\hline $\begin{array}{c}\text { First } \\
\text { Code }\end{array}$ & $\begin{array}{c}\text { Year of } \\
\text { Enrollment }\end{array}$ & $\begin{array}{c}\text { F means Year 93 (enrolled at age 4) } \\
\text { S means Year 94 (enrolled at age 5) }\end{array}$ \\
\hline $\begin{array}{c}\text { Second } \\
\text { Code }\end{array}$ & Sex & $\begin{array}{c}\text { G means girl } \\
\text { B means boy }\end{array}$ \\
\hline $\begin{array}{c}\text { Third } \\
\text { Code }\end{array}$ & $\begin{array}{c}\text { Serial } \\
\text { Number }\end{array}$ & $1 \sim 10$, as there were 10 children \\
\hline
\end{tabular}

Table 3. Nature Activity Curriculum

\begin{tabular}{|c|c|}
\hline Unit Name & Unit Goal \\
\hline $\begin{array}{c}\text { Shapes and Colors - See } \\
\text { Them All }\end{array}$ & \multirow{2}{*}{$\begin{array}{l}\text { Develop the children's ability to observe the environment } \\
\text { Train the children to observe and explain changes in nature } \\
\text { Help the children learn to use appropriate words to describe the things they observe }\end{array}$} \\
\hline $\begin{array}{l}\text { Shapes and Colors - } \\
\text { Treasures on the Beach }\end{array}$ & \\
\hline Others and $\mathrm{Me}-$ Kiss Taiwan & $\begin{array}{l}\text { 1. Learn about latitudes, longitudes, and where the Earth is in space, using a tellurian globe } \\
\text { 2. Learn about the layout of Earth's lands and seas, using a tellurian globe } \\
\text { 3. Be familiar with Taiwan's geographic location } \\
\text { 4. Be familiar with Taiwan's geographic environment and its particular geographic landscape } \\
\text { 5. Be familiar with Taiwan's unique flora and fauna }\end{array}$ \\
\hline $\begin{array}{l}\text { Others and } \mathrm{Me}-\text { Whispers of } \\
\text { Mountains and Waters }\end{array}$ & $\begin{array}{l}\text { 1. Use class activities to cultivate the children's concern for nature } \\
\text { 2. Understand the importance of soil and water conservation through measurement instruments and } \\
\text { actual operation } \\
\text { 3. Cultivate a passion for and understanding of environmental, forest and water conservation }\end{array}$ \\
\hline $\begin{array}{c}\text { Growing-Up - The Little } \\
\text { Bean's Wish }\end{array}$ & $\begin{array}{l}\text { 1. Understand the structures and features of the various types of seeds } \\
\text { 2. Learn about how plants grow through seed planting } \\
\text { 3. Learn about how different factors affect seed growth through seed planting } \\
\text { 4. Understand the relationship between seeds and plant propagation by observing seeds } \\
\text { 5. Learn how to categorize seeds using their various characteristics }\end{array}$ \\
\hline $\begin{array}{c}\text { Midterm Evaluation - Guess } \\
\text { What's Inside }\end{array}$ & $\begin{array}{l}\text { 1. Use the five senses to observe the object in the mystery box } \\
\text { 2. Raise appropriate, logical questions regarding the object in the mystery box } \\
\text { 3. Use instruments to measure and compare } \\
\text { 4. Observe object characteristics and draw appropriate sketches as records } \\
\text { 5. Come up with innovative ideas when faced with problems or questions }\end{array}$ \\
\hline $\begin{array}{l}\text { Four Seasons - The Four } \\
\text { Seasons Concerto }\end{array}$ & $\begin{array}{l}\text { 1. Learn to record measurements and observation results } \\
\text { 2. Understand the meaning behind weather related information } \\
\text { 3. Make simple instruments to determine wind direction and measure weather phenomena such as } \\
\text { wind speed and rainfall }\end{array}$ \\
\hline Festival (making a chart of & Nurture the children's ability to observe the environment \\
\hline
\end{tabular}




\begin{tabular}{|c|c|c|}
\hline $\begin{array}{l}\text { seasonal festivities, festival } \\
\text { food, relating agriculture and } \\
\text { festivities) }\end{array}$ & $\begin{array}{l}2 . \\
3 .\end{array}$ & $\begin{array}{l}\text { Have the children use appropriate words to express what they have seen } \\
\text { Let the children know about Chinese festivals and the special days of the seasons, and let them be } \\
\text { able to observe changes relating to the natural environment } \\
\text { Make a simple shadow pole; observe changes in the sun and changes to the pole's shadows }\end{array}$ \\
\hline $\begin{array}{l}\text { Family - Take charge of } \\
\text { Environmental Protection } \\
\quad \text { around the Family }\end{array}$ & $\bullet$ & $\begin{array}{l}\text { Learn to conserve the environment around the family, and understand the meaning and importance } \\
\text { of environmental protection } \\
\text { Understand the meaning of and methods for family environmental protection }\end{array}$ \\
\hline $\begin{array}{l}\text { Family - The Magician in the } \\
\text { Kitchen }\end{array}$ & & $\begin{array}{l}\text { Through experiments, enhance the child's interest for the physics and chemistry of everyday life } \\
\text { Learn to experiment using common kitchen seasoning }\end{array}$ \\
\hline
\end{tabular}

\subsection{Research Tools}

\subsubsection{Classroom Activity}

In this research, six themes were woven into the target goal for the classroom activities: relationship, pattern, change, individuality, cycles, and environment. Based on the main themes, six units of activities were designed. The six units, in chronological order, were "shape and colors", "Others and me", "Growing-up", Festival", "Four Seasons", and "Family". Details are listed in Table 3.

\subsubsection{Archives of Participating Children}

In this paper, several artworks from different children are introduced to unveil children's unique thinking and talent. The focus of observation were on characteristics of creativity and problem solving ability, such as: excellent observation (observation); abundant knowledge (knowledge); verbal expressive ability (verbal), logic-reason ability (reasoning); critical thinking (critical); insightfulness (insight); fluent thinking (fluency); flexible thinking (flexibility); original thinking (originality); elaborative thinking (elaboration); vivid imagination (imagination) and excellent sense of humor (humor).

\subsubsection{Data Collection and Processing}

The course lasted for one school year. There were 18 two-hour classes every semester, for a total of 72 hours. Oral data were videotape recorded and transcribed by undergraduate students. Then the researchers validated the notes and transcripts by listening to the original videotapes. After that, the researchers coded the tapes and notes and worked with the resulting text to obtain a comprehensive picture of the children's language performance in class.

Data which were collected through class observation were analyzed by content analysis. The aim of the content analysis is to reach the concepts that could explain the collected data and relations between concepts. Collected data in the research were also codified. Codes are categorized by cross - sectioning method after arranged in a format that suitable to the content. Then data of the research were read by two different researchers and made codifying by them. $92 \%$ of similarity has found between codifying of the researchers. Over $90 \%$ of this similarity reflects the reliability of the study. Consensus and disagreements were discussed and necessary adjustments have done.

In this study, we started coding the oral data collected with units and course titles as the first and second codes, and assigned the third code based on the date (year, month and day) in which the speech took place. The fourth code referred to the personal code of the child who did the artwork as every child completed his/her project during each class. For example, the artwork created by child SB2 was identified as "Others and $\mathrm{Me}$ - Whispers of Mountains and Waters- SB2". Whenever a child finished a project, the teacher asked the child to come up with his/her own meaning and wrote down the answer on the piece or record it separately.

In analyzing the data gathered in this study, relevant literature was used as a basis for categorization and induction. Key sentences and paragraphs were underlined in the transcript or the children's description of their work; meanwhile, looking for related literature review provided different aspects of analyses. The categories were then adjusted after repeated reviewing the video data, transcripts, and children's artwork, as well thorough discussion with the co-instructors to ensure the titles of categories provided a distilled description of the children's performance.

\section{Research Results}

The following characteristics of the gifted and talented young children and creativity or problem solving ability were found after analyzing the collected observational data on teacher-child and child-child interactions as well as the children's artworks.

\subsection{Keen Powers of Observation and Abundant Knowledge}

Observation is the most fundamental and important science process skills for children to develop. Only by keenly observing the surrounding and recognizing the early warning signs can we move on to investigate the possible causal relationships between different phenomena. In the unit "Seasons-The Four Seasons Concerto", the teacher presented pictures of the four 
seasons, followed by initiating the conversation.

Teacher: Find the differences between spring and summer.

FB1: I think the leaves look different in spring and summer. In spring new leaves are bit curled. (observation)

FB2: Flowers seem to look different between spring and summer. (observation)

Teacher: Yes, the colors for spring are tender shoots, isn't it? Besides color, FB1 found another way to identify seasons. What else does he distinguish the differences between the four seasons? (In order to relate life experience to science concept, the teacher guided children to feel the differences of the four seasons by observing environmental objectives. )

SG7: Animals. (observation)

SB4: Because there is a snake in the picture. (observation)

Teacher: That's right! Animal's behavior changes with the seasons. Snakes come out in spring. Have you seen snakes in winter? (Everyone shakes with their heads.) (In order to inspire their thinking, the tone of "winter" was raised to catch children's attention to think what else they can see in different seasons.)

Teacher: Snakes hide in the winter, because they are poikilothermic animals. They need to live in warm caves in winter.

SB4: It's the easiest to see this in summer (pointing at the drawing), a termite nest. (observation)

$<$ Seasons-The Four Seasons Concerto $>$

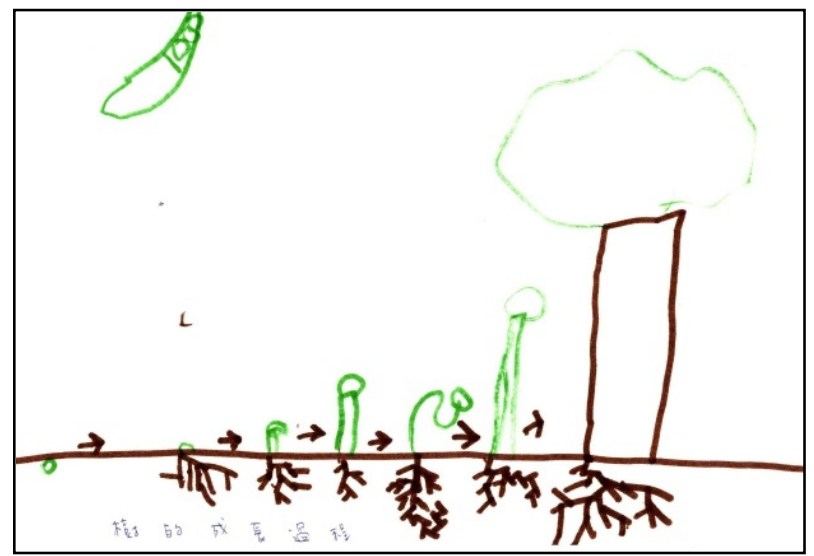

The Little Bean's Wish

$<$ Others and Me — Kiss Taiwan-941029_FB1 $>$

Figure 1. Artwork of Child SB6

In the unit "Growing-up-The Little Bean's Wish", the children planted various types of bean seeds and observed the growth process of legumes. Figure 1 shows what the child observed with the seeds during the process of germination. From the picture, we can tell there were 7 steps growing, starting from left to right, illustrate the germination of a bean seed. The child SB6 observed that the seed grew in the same spot and developed a strong root system (observation). After the root absorbing water, the cotyledons were exposed and broke through soil surface as the epicotyl emerges. The expanded cotyledons provided nourishment to the growing plant so that the embryonic plant began to grow and develop (observation \& knowledge). The simple line drawing in this Picture shows a rich, delicate features observed by the Child SB6.

In the unit "Festival", the teacher utilized a higher-order question by creating a cognitive challenge through a predictively problem-solving task. The children presented how they might predict weather changes through observations of signs from nature.

Teacher: Back in the past, our ancestors did not have scientific instruments to forecast weather changes like we do. So how did they know what the weather would be like the next day?

SB3: See if the clouds are red. (observation \& knowledge)

Teacher: Hmm... see "changes" in the clouds...(With a tone of doubt, the teacher tried to extend children's thinking in terms of "change" point of view and encouraged them to describe more specifically.)

SB3: Look at changes in the clouds. If the clouds are rather thick, then it might rain the next day. (knowledge \& flexibility)

FB1: Clouds like that might not mean rain... it's better to look at dragonflies. (critical)

Teacher: FB1 found another way. (To promote children's fluent and critical thinking, the teacher agreed with FBI's proposal.)

FB1: If the dragonflies fly higher, then the weather might be good. If they fly lower, it might rain! (knowledge)

Teacher: Very good! If a dragonfly flies very low... particularly if many dragonflies fly very low, then that means it might rain.

FB1: If a lot of worms come out, it means it'll rain tomorrow. (fluency)

$<$ Festival-Understanding the Relationship between Agriculture and Festivities $>$

In addition, through the drawing Child FB1 made in the unit "Others and Me-My Lovely Hometown", he showed the relative geographic positions and respective weathers for Taiwan and its neighboring islands and countries, including Japan, China and the Philippines (Know). As well, he correctly illustrated the various landmarks and scenic sites around Taiwan, including Taipei 101, airplanes at the Taoyuan International Airport, the great Buddha on Eight Trigram Mountain, the sunrise and steam trains of Alishan, great ships at the Port of Kaohsiung, and the hot springs of east Taiwan (Figure 2). It is worth to be mentioned here that Child FB1 is a child suffer from Asperger's syndrome, however he is very bright and good in nature knowledge. He always communicated with teachers and peers through topics related with nature. 


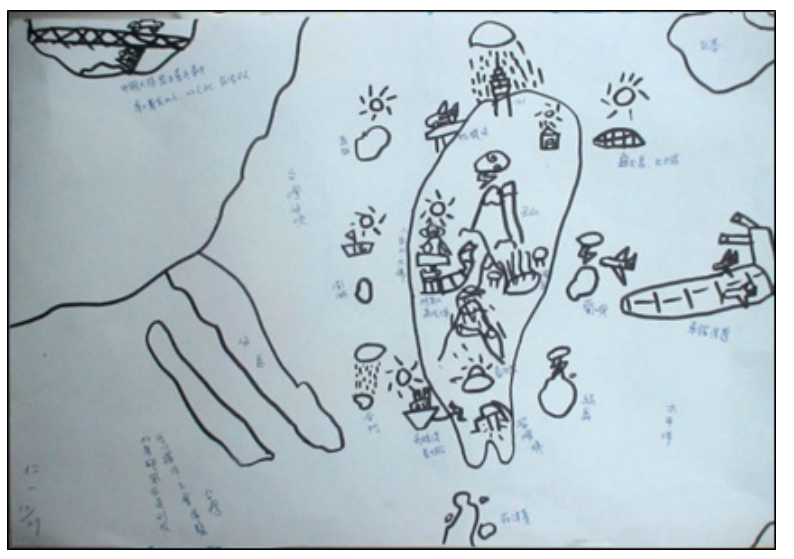

Taiwan's neighboring islands and current weather: at Taiwan's 1 o'clock direction is Turtle Island (sunny); at the 3 o'clock direction we have the island of Lanyu (thundering below cloud), with airplanes above and battleship to the right for protection; at the 5 o'clock direction we have Green Island (thundering below a cloud); Kinmen is at 7 o'clock (rainy); Penghu is at 9 o'clock (sunny); Matzu is at 10 o'clock (sunny).

Taiwan itself and its weather: Taipei 101 (rainy); on the bottom left of 101 is Taoyuan International Airport; the two mountains in the middle represent Yushan; on the left of Yushan is the great Buddha on Eight Trigram Mountain (sunny); underneath the Buddha is Alishan's steam train; to the steam train's right is the hot spring of east Taiwan; go down a bit and we have Alishan's sunrise; left of the sunrise are great ships in the Port of Kaohsiung.

Taiwan My Home Town

$<$ Others and Me-Kiss Taiwan-941029—SB6>

Figure 2. Artwork of Child SB6

Followings were description excerpt from a dictation by FB1's (see Figure 2), there we can tell his knowledge on geography were far beyond his peers'.

Country: below Taiwan lies the Philippines. This is Japan (points to the upper right), and this is China (points to the left of Taiwan).

Neighboring islands and weather: at Taiwan's 1 o'clock direction there is Guishan Island (sunny); at 3 o'clock we have Orchid Island (thundering below cloud), with airplanes in the sky and battleship to the right providing protection from air and sea attach; at 5 o'clock we have Green Island (thundering below a cloud); Kinmen is at 7 o'clock (rainy); Penghu is at 9 o'clock (sunny); Matzu is at 10 o'clock (sunny).

Taiwan and its weather: Taipei 101 (rainy); on the bottom left of 101 is Taoyuan International Airport; the two mountains in the middle represent Yushan; on the left of Yushan is the great Buddha on Eight Trigram Mountain (sunny); underneath the Buddha is Alishan's steam train; to the steam train's right is the hot spring of east Taiwan; go down a bit and we have Alishan's sunrise; left of the sunrise are great ships in the Port of Kaohsiung.

\subsection{Superior Verbal Expressive, Logical Reasoning and Elaborative Ability}

Compared to their peers at the same age, gifted and talented children develop verbal abilities earlier, speak with more precision, and can correctly use words and terms not yet expected at their age [13]. For example, in the first outdoor observation trip the teacher explained the rules: "Once we go outside, you cannot move beyond a five-pace distance from me.

Front, right, left, rear, all must stay within a 5 step range." Immediately, SB4 raised his hand and said, “That's a 360 degrees' circle." (knowledge \& verbal) $<$ Shapes and Colors-See Them All-20050924>

Scientific forms of discourse for active discussion around science activities prompt children to reason and use scientific language gradually. By changing the prosodic clues, teachers not only adjust children's communicative behaviors and facilitate vocabulary development but scaffold concept of science. For gifted children, to understand word meanings precisely, the children immediately raised questions when they heard abstract terms. For example, in the unit "Festival", the teacher discussed "abundant production" with the kids.

SB5: What does abundant production mean?

Teacher: Abundant production means they produce a lot right now. The word "Abundant" means a lot.

SB6: The word "Abundant" means a lot.

Teacher: That's great, SB6! Now you see?

SB5: We kids don't have an abundant production period. Dinosaurs had an abundant production period, called the Cretaceous period or something. (Verbal)

Teacher: It's Jurassic period. What SB5 really means, there are children born every day, not in specific season. (By explaining "abundance", the teacher correlate the concept with daily event to increase other children's efficacy for approaching the same task.)

SB6: Actually, somebody born every day. We just don't see it. (reasoning)

\section{$<$ Festival-Knowing Festivities, Festival Food-20060422>}

In general, children interpret words and phrases drawn on personal experience, but the gifted children in this course were found to be substantially further reach beyond phrases taught directly, e.g. using a metaphor of their own to demonstrate their understanding of a concept.

In "My Lovely Hometown" lesson, the teacher played with a terrestrial globe with the children to motivate their learning and continued questioning that brought the widest perspective to issues contributing a breadth and logic of thinking. At the beginning of the class, the children were asked to express their opinions freely about the possible ways earth rotating around itself.

Teacher: Does anybody know what a terrestrial globe is? (SB3 raised his hand). (The teacher initiated the activity by making the children to try to define what a terrestrial globe is.)

SB3: Artificial representations of the earth. It can rotate around itself using that (points at the shaft of the tellurian globe) ...

Teacher: So why is it rotating?

SB6, SB5: I know!

FB1: $\sim$ Rushed to the globe $\sim$ The earth rotates like this! 
(spinning the globe clockwise) (Observation)

Teacher: So which way does the earth turn, this way (spinning the globe clockwise) or this way (spinning the globe counterclockwise)? (Based on the children's responses and interests, the teacher switched her question from "why" to "how" the terrestrial globe rotates.)

SB4: I know! It's different every day! For example, it rotates this way the first day (SB4 spinning the globe clockwise) and this way the next day (spinning the globe counterclockwise). (elaboration)

Teacher: Now there are three kinds of answers. The first one rotates in a right-hand manner (clockwise). The second one rotates in a left-hand manner (counterclockwise). The last one rotates clockwise for the first day and counterclockwise the next day. Are there any other answers?

SB3: It could be standing still at all. (reasoning \& insight)

When Child FB1 declared the first (clockwise) method, the teacher, for the first time, asked the kids whether the Earth turns clockwise or anticlockwise. When he moved on to ask if there were other possibilities, Child SB4 thought that "maybe the Earth turns clockwise one day and anticlockwise the next". Child SB3 then proposed, "Maybe the Earth doesn't turn at all." Through this interaction we find that the kids established a total of four hypotheses for Earth rotation.

Problem analysis is the first step towards problem solving. Identifying in the first instance can be indicative of creativity and giftedness [63]. Once the teacher concluded that there were 3 possibilities for Earth's self-rotation, SB5 raised a 4th possibility "The Earth doesn't move at all." This goes to show that chains of questions and discussions can really challenge children's views, drive them to think and solve problem in systematic lists of the different possibilities. Afterwards, SB3 brought up Sun's existence.

SB3: I see that the Sun moves. (observation)

Teacher: So the Sun moves and the Earth doesn't move?

SB4: No, it's the Earth that moves. The Sun sits in the center and doesn't move. (SB4 stands and rotates himself on one spot, demonstrating how the Earth moves). (knowledge)

Teacher: So the Sun doesn't move, but the Earth sits on the side and just keep spinning?

SB7: If the Earth doesn't spin, we won't be able to tell night from day. (reasoning)

Teacher: Why would it be that if the Earth doesn't spin, we can't tell night from day?

(The teacher asked children a clarifying question to construct children's conceptual knowledge.)

SG7: This is day (points side of the globe that faces the light), that is night (points to the side that's away from the light).
Teacher: So the Sun doesn't move, the Earth moves (as in spins around itself), right?

SB6: Right!

SG8: The Earth does turn, but it takes 24 hours for it to turn once. (elaboration)

SG7: Right!

SB6: It spins once every 24 hours. (reasoning)

SG7: Right! Every 24 hours.

When Child SB3 brought up the Sun, the focus moved away from "Earth itself" and extended to include "the relational interaction between the Earth and the Sun". Mentioning the Sun did not confound these children; instead, it became a reference point from which they determined Earth's rotation. SB6 and SB7, using the relationship between the Sun and Earth, night, and day, concluded that "the Earth rotates around the Sun, and rotates once every 24 hours, which is why we have day and night." Thus far, the teacher and children made the preliminary conclusion that "the Earth rotates around the sun", and that "every rotation takes 24 hours".

According to Gallas [18], a scientific idea is often the result of many interpersonal exchanges, of interaction with materials, and of false starts. Although not all scientific phenomenon can be observed, preschoolers can integrate phenomenon they can see and their knowledge and also reason possible answers.

Gifted children in this study could notice association between different variables which may confuse them, and then make inference based on scientific knowledge as well as conclusions which Harlen [25] suggested 8-12 year-old children can do.

Children from this program often demonstrated imaginative personifications over their course activities, filling each class with laughter and fun. Not only did they possess a wide range of knowledge about nature, they even imagined themselves to be nature's animals, endowing them with human sentiments. Once, while discussing "domestic birds" and "domestic animals", the children were asked to describe "character features" of animal actions.

Teacher: One kind is called domestic birds, and another called domestic animals. What are birds, what are animals? I just said that birds are creatures with feathery wings. What kind of birds would you keep about the house?

SG7: Chickens. (reasoning)

FB2: Ducks, Geese. (fluency)

Teacher: That's great, FB2! These are all domestic birds. Would you keep a sparrow as a pet?

SB6: Probably not (reasoning)

SB5: Domestic animals are the cats and dogs we keep around the house. So domestic animals don't really have manners, pets have better manners. (reasoning \& elaboration)

$<$ Others and Me - My Lovely Hometown-> 
Not only did Child SB5 personify animals, he even imposed rules of human social behavior upon his characters, which was really quite interesting.

\subsection{Diverse and Flexible Problem-Solving Ability}

As opposed to being "provided with solutions," as would happen in kindergartens, children must solve their problems "independently", or through "diverse" strategies, if they were to become true problem solvers.

In the unit "Four Seasons-The Symphony of Four Seasons", the teacher displayed a Taiwan`s rainfall distribution chart. Child SB4 came up with a concept of reservoir to design a rain collector using a variety of multimedia materials such as clay, crayons and toothpicks. Problem-solving results were presented as follows. (Figure 3). First, according to Child SB4, a levee was constructed by planting trees surrounding the water channel to block the entry of ants (flexibility). Secondly, a backup reservoir was implemented to accommodate the overflow (problem solving). Lastly, a lab was set up to monitor and study the rainfall at the end of the channel (problem solving).

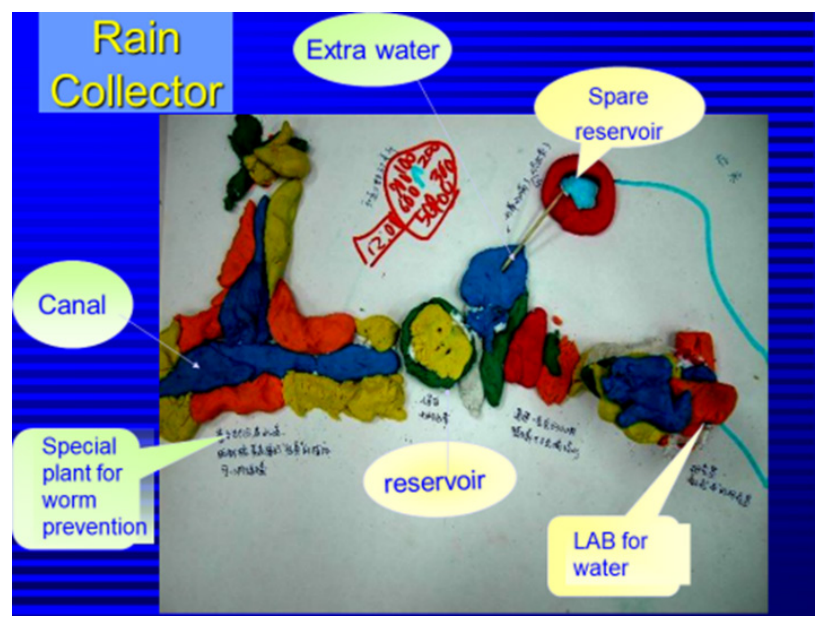

Rain collector

$<$ Four Seasons - The Symphony of Four Seasons - 950325 - SB4>

Figure 3. Artwork of Child SB4

The other boy SB3 has another idea of rain collector. His rain collector could alert while water was full (problem solving). The purpose was to allow researchers came out from the lab to dump water (problem solving). The stabilizer on the bottom was designed with orange peel oil for worm prevention (flexibility). Canopy on the entrance of lab and fingerprint examiner were set up for entering, acid rain detector was built inside (knowledge) (as shown in Figure 4).

In general, children at the age of 5 are only capable of considering two factors for solving natural problems simultaneously. By comparison, gifted children like SB4 and SB3 can memorize complicated information in details and correlate multiple information reasonably.

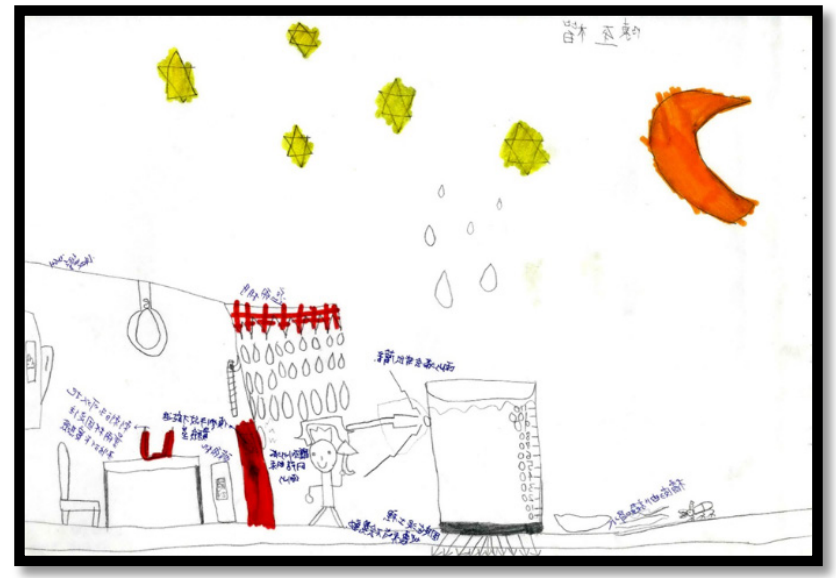

Rain collector

$<$ “Four Seasons - The Symphony of Four Seasons" — 950325 - SB3>

Figure 4. Artwork of Child SB3

\subsection{From Knowledge Blooms the Flowers of Imagination and Humorous}

Outside of personifying descriptions, when the teacher and the children shared their observations for spring's various phenomena, certain children's use of exaggerated expressions and body language when they express their views could really make you spelt your coffee.

Teacher: It's now March. What season March is in?

Children: Spring.

Teacher: And what special scenery do we see in spring?

SB5: Flowers will bloom, but not like they do in summer, when they bloom as big as your face (SB5 spreads his palms beside his face and opens his mouth really wide with an exaggerated way.)

\section{$<$ Seasons-The Four Seasons Concerto- $>$}

In pre-school aged children laughter occurs increasingly in playful interaction with others [43]. Not only facial expression and body movements, but drawing is also one of children's favorite ways of expressing their ideas and thoughts. Beyond acting as a record of their education, their drawings are like mirrors of their hearts, capable of reflecting what they truly felt when making the drawings, without disguise. When the teacher asked the children to make freeform creations related to the course subject (fruits), SB6 endowed his protagonists-two oranges-with "life". In terms of content, the child has moved beyond self-centered development and demonstrated his ability to consider interpersonal relationship (the two oranges were husband and wife). In just one picture, he presented both temporal (the present time and the Mesozoic Period, when dinosaurs roamed) and spatial (the worlds of humans and dinosaurs) transitions through the orange's "dream". The storyline had the orange jump back to the present time and space because he encountered danger. In terms of expression, 
not only did the teacher refrain from giving limitations, he or she even encouraged the children to use diverse expressive methods, both before the exercise and while reviewing their artworks. As a result, we saw a form of expression seldom created by young children: comic strips (see Figure 5).

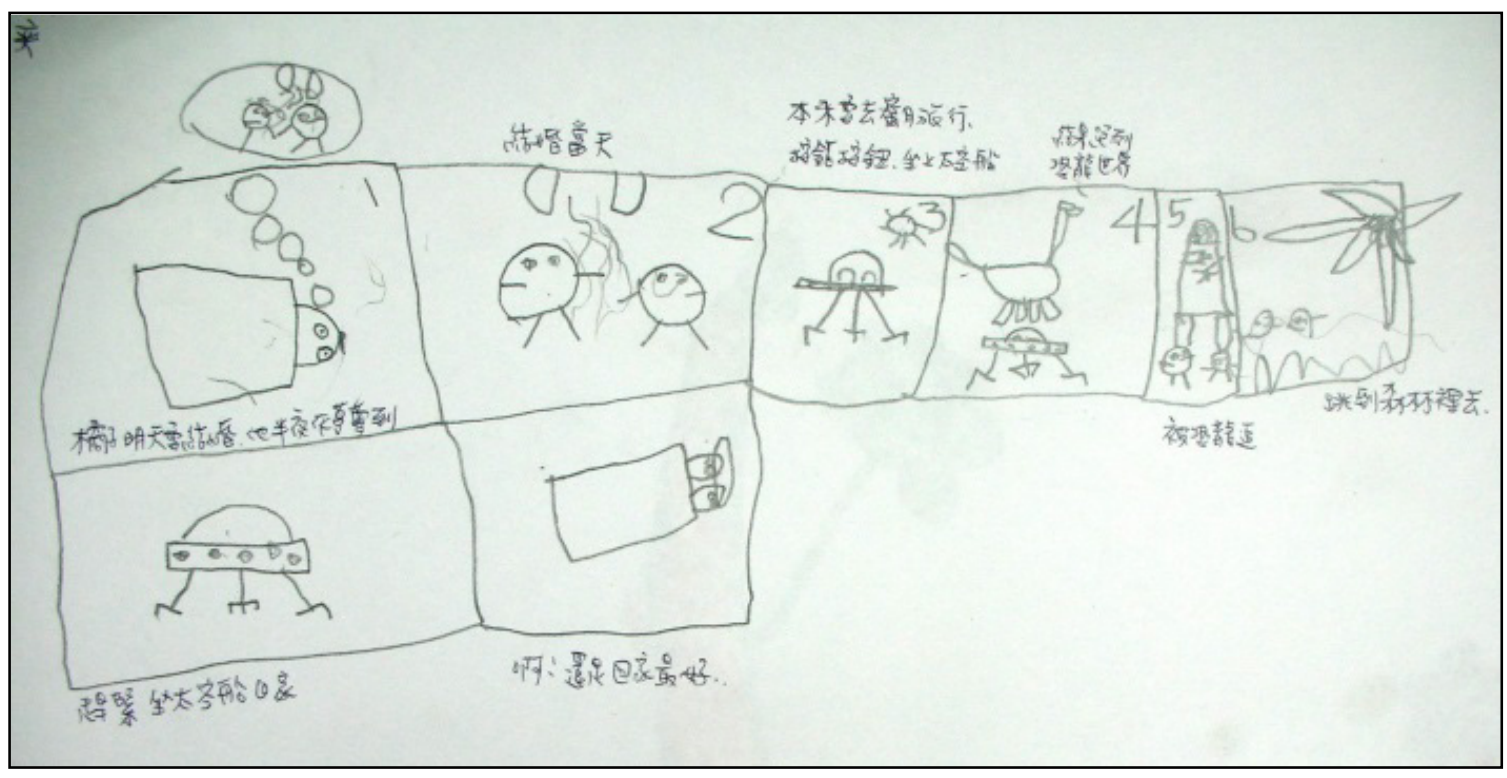

Work Description (upper left to lower right, as dictated by Child SB6):

Box 1: Orange was getting married the next day, and he dreamt at night...

Box 2: The day of the Wedding...

Box 3: They were going to go on a Honeymoon, but they pressed the wrong button and got on a spaceship instead

Box 4: They arrive in a world of dinosaurs

Box 5: They were chased by dinosaurs

Box 6: They jumped back into the forest

Box 7: They got back in the space ship really quick and went home

Box 8: The two Oranges sat on their bed, thinking: Ahh... it's good to be home!

Make a story about fruits

<Midterm Evaluation—Guess What's Inside—950304—SB6>

Figure 5. Artwork of Child SB6 


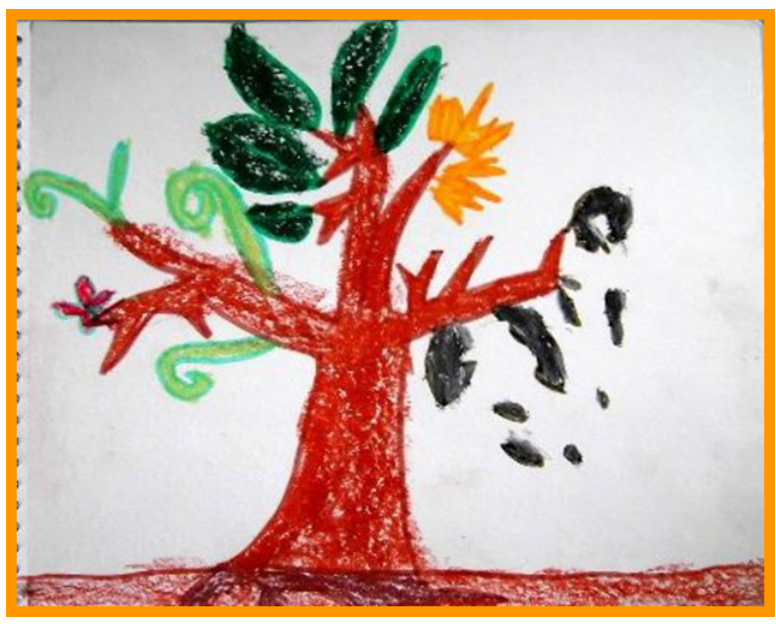

Expression of seasons

$<$ Four Seasons-The Symphony of Four Seasons - 950311-SB1>

Figure 6. Artwork of Child SB1

Compared to the average young children who may have different plants or scenery in different seasons, or a seasonal scene in a picture, FB1 only shows changes in the four seasons through the change of one tree leaf. The performance of the force is quite unique. In Figure 6, seasonal change was shown on the same tree with leaf's shape and color adaptation. The leaf of spring was curved and light green; that leaf of summer was fatty and deep green; the leaf of fall was withered and yellow and the one of winter's was faded (imagination).

In Figure 7, when teacher asked the boy to tell the story of the picture, the young boy described four seasons with a picture. In the spring, the bunny and the small tree became good friends, and the rabbit invited the tree to eat carrots and showed their friendly relationship. In the summer, the leaves became bigger, but the bunny could not find a tree friend, which deeply depicted the expression of the rabbit's disappointment. In the autumn atmosphere, the bunny could not find its tree friend again, and started a sad mood, but the tree saw the bunny, he smiled happily; when the winter was coming, the leaves were falling, the trees were bare, and the bunny becomes very sad again.

In the upper right corner of the summer, the leaves were lush, humorously exaggerated to describe the bunny could not find the tree friend. In the lower right corner of the winter, the trees were bare, and the body of the little white rabbit was not drawn. Instead, the boy FB9 creatively designed the body with a series of numbers. From the number 1 to the number 8 and then back to 1 , the rabbit's body came out! (humor and imagination). What is even rarer was that FB9 could break through the plane and expressed the four seasons in a three-dimensional way (creativity).

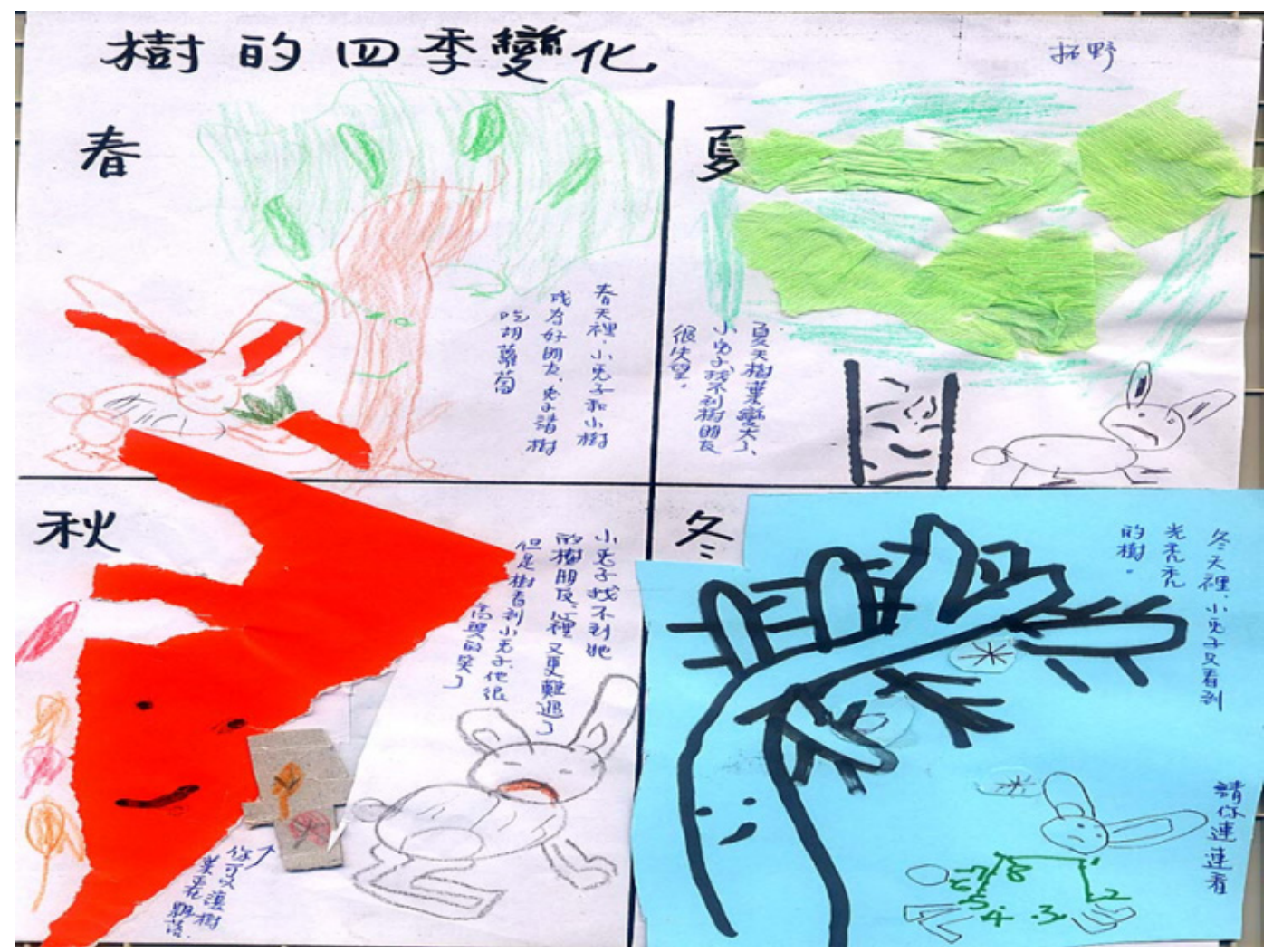

Tree in Four Seasons

$<$ Four Seasons-The Symphony of Four Seasons-950311-FB9>

Figure 7. Artwork of Child FB9 
Finally, a sense of humor was detected by the other boy SB10 (Figure 8). One afternoon, the boy sat beside his mother when one of the instructors was talking with the mother. The boy seemed unconcentrated, and was then asked to draw a portrait of the instructor. The boy drew very fast and finished the portrait in 10 minutes (fluently). He looked very happy, smiled and signed with a lion. He said: "my name is Leo; Leo is the abbreviation of lion" (humor).

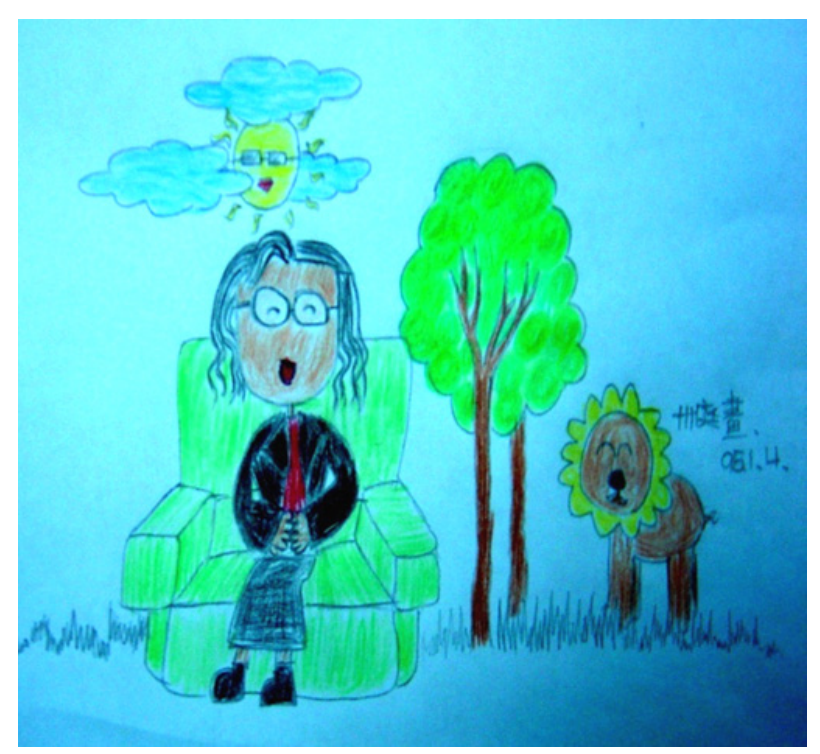

Figure 8. Artwork of Child SB10

\section{Discussions and Conclusions}

\subsection{Discussion}

Gifted and talented children frequently demonstrate advanced comprehension and memory skills; they can store large amounts of information and remember them for long periods of time. They can also find relationships between different events and things and can organize and categorize them accordingly. Add these to the fact that they tend to use more complex vocabularies in their writing and everyday conversation [60], adults often are surprised at how much and how varied their language is. Therefore, a higher level of accumulated knowledge and thinking abilities is one characteristic often attributed to exceptionally gifted and talented children $[13,23,26,27,35,53,54]$.

From an early age, gifted individuals display superior strategic abilities compared to same-aged peers [54]. They were precocious in their levels of reasoning abilities, and descriptive knowledge, and used a variety of strategies when solving problems, especially when facing novel challenges [58]. When stimulated by challenges, a high-level development of ability and the process of finding answers and solving problems enable them to see its conditions, distinguish relations, deepen and clarify their knowledge and modification of solutions, learning as a result.

Both humor and creativity involve a thinking process that includes connection, analogy, switching perspectives, and new ways of looking at things [50]. Many tests for creativity also considered one's sense of humor as part of one's creativity. Murdock and Ganim [47] analyzed past definitions and researches and found a high correlation between humor and creativity. McGhee [44,45] did a series of research on children's sense of humor, and after consolidating relevant research concluded that people's abilities to create discord, exaggerate, comprehend, appreciate humor, and successfully resolve problems are positively related to their cognitive ability scores measured through IQ tests. At the same time, gifted children were proven to possess creativity and sense of humor $[26,35,46]$. Such a sense of humor not only exists in language, but can also be shown through drawings and other means of expression.

In this research, conversation analysis results and relevant literature point toward the conclusion that developmentally, gifted children are ahead of their peers. In addition to the usual gifted children characteristics, such as being sharp observers, being rich in general knowledge, and having superior reasoning and elaborative wording capabilities, they also exhibit quicker development of their oral expression capabilities. While teaching, teachers need to use subjects that children find interesting and lure them into freeform imagination and logical reasoning, to evoke natural, original, genuine trains of thought in children. When categorizing and analyzing, the teacher must look past the literal meanings of words that children use in oral expressions and, through actions and spontaneous questioning, obtain an accurate analysis of the child's conceptual intension. Tobin, Tippins and Gallard [59] stated that only through problem solving may one understand scientific knowledge. In our research, not only are gifted children strongly motivated to solve problems, furthermore, they have fluently, flexible, and original way of resource finding for more resolution strategies and rarely reuse the same strategies. They can analyze the problem and come up with the best solution from their store of known strategies [53].

\subsection{Conclusions}

Researches of experts and novices have indicated that experts can come up with more problem solving strategies and can evaluate the effectiveness of resolution proposals. A science teacher may model, scaffold children through various strategies in an interaction-based class. From the above conversation, one can find that the teacher, aside from guiding the children towards "directly" solving the problem, also guided them towards "indirectly" solving the problem, which was "finding resources." When faced with 
a problem, a child must consolidate knowledge and prior experience. But the child, being limited in background and cognitive abilities, might also think beyond problem solving itself and seek for assistance. Thought processes like SB6's "Ask people”, or SG7's "Use your ear and listen to what others talk about more." were also fairly flexible ways.

Gifted children are often intrinsically interested in science, especially preschoolers. However, few studies have been done on the topic of their performance on science activity. This research took child-centered conversations, gathered data, and analyzed conversation contents and artworks to gain a deep understanding of gifted children's characteristics. Through the ways teacher facilitating the question and problem solving behaviors, gifted young children profited from such kinds of enrich activities. The participated children changed some misconcepts from teacher-student interaction; elaborated their thinking and expressive skills from teacher's feedback and also increased their problem solving abilities. The great potentials could be discovered from their amazing artworks and interesting words. Because of their accumulated knowledge and rapid pace of learning, the more and earlier enrichment activities provide for these bright young learners which meet the children's talent domain and uneven levels of developmental needs across cognition, social interaction and emotion; the more intellectual growth they will have.

\section{Acknowledgements}

This work was supported by the National Science Council, Taiwan and subsidized by the National Taiwan Normal University (NTNU), Taiwan, ROC.

\section{Highlights}

1. Classroom dialogue helps teachers understand learners' characteristics.

2. The gifted children showed keen powers of observation and wider general knowledge.

3. They also had superior verbal expressive, reasoning, and elaborative abilities.

4. The gifted children were more fluent and flexible than their peers.

5. The gifted demonstrated creative reasoning and highly imaginative ideas as well.

\section{REFERENCES}

[1] Bandura, A. (1989). Regulation of cognitive processes through perceived self-efficacy. Developmental Psychology, 25(5), 729-735.
[2] Bayanova, L. (2014). Compliance with culture rules of children having different level of creativity. Social Behavioral Sciences, 146, 162-165

[3] Berninger, V. W., \& Yates, C. M. (1993). Formal operational thought in the gifted: A post-Piagetian perspective. Roeper Review, 15(4), 220-224.

[4] Bruner, J. S. (1978). The role of dialogue in language acquisition. In A. Sinclair, R., J. Jarvelle, and W. J. M. Levelt (Eds.), The Child's Concept of Language (pp.241-256). New York: Springer-Verlag.

[5] Bruner, J., \& Haste, H. (1987). Introduction. In J. Bruner \& H. Haste (Eds.), Making Sense: The child's construction of the world. New York, NY: Routledge.

[6] Brunton, P. \& Thornton, L. (2010). Science in the Early Years. London, Sage.

[7] Carter, K. R., \& Ormrod, J. E. (1982). Acquisition of formal operations by intellectually gifted children. Gifted Child Quarterly, 26, 110-115.

[8] Chen, R. H., \& Chen, H. (1997). The Manual of the Chinese Version of the Wechsler Primary and Preschool Scale of Intelligence-Revised (WPPSI-R). Taipei: Chinese Behavioral Science Corporation.

[9] Cohen, L. M. (1987). Techniques for studying the interests of infants and young children. Gifted International, 4(2), 15-32.

[10] Cohen, L. M., \& Kim, Y. M. (1999). Piaget's equilibration theory and the young gifted child: A balancing act. Roeper Review, 21(3), 201-206.

[11] Cukierkorn, J. R., Karnes, F. A., Manning, S. J., Houston, H., \& Besnoy, K. (2007). Serving the preschool gifted child: Programming and resources. Roeper Review, 29, 271-276.

[12] Daglioglu, H. E., Çalısandemir, F., Alemdar., M. \& Bencık, Kangal, S. (2010). Examination of human figure drawings by gifted and normally developed children at preschool period. Elementary Education Online, 9(1), 31-43

[13] Davis, G. A., \& Rimms, S. B. (1998). Education of the gifted and talented (4th ed.). Boston, MA: Allyn \& Bacon.

[14] DeVries, R. (1974). Relationships between Piagetian, IQ, and achievement assessments. Child Development, 45, 746-756.

[15] Fan, C. F. (2001). A study on using different models for identifying preschool gifted children-The experience of a public kindergarten in Taipei, Taiwan. (Master's thesis). Available from National Digital Library of Theses and Dissertations in Taiwan.

[16] Feldman, D. H. (2004). Piaget's stages: the unfinished symphony of cognitive development. New Ideas in Psychology, 22, 175-231.

[17] Gallas, K. (1994). The language of learning: How children talk, write, dance, draw, and sing their understanding of the world. New York, NY: Teachers College Press.

[18] Gallas, K. (1995). Talking their way into science: Hearing children's questions and theories, responding with curricula. New York: Teachers College Press.

[19] Ginsburg, H. P., \& Opper, S. (1988). Piaget's theory of 
intellectual development. Englewood Cliffs, NJ: Prentice Hall.

[20] Goodenough, F. L (1926). Measurement of intelligence by drawings. New York: Harcourt Brace.

[21] Goodnow, J. (1977). Children's drawing. Cambridge, MA: Harvard University Press.

[22] Gross, M. (1999). Small poppies: High gifted children in the early years. Roper Review, 21(3), 207-214.

[23] Gross, M. U. M. (1993). Exceptionally gifted children. New York, NY: Routledge.

[24] Haensly, P. A. (1999). The role of cognitive style in transforming preschoolers' gifted potential. Roeper Review, 21(4), 272-280.

[25] Harlen, W. (2000). Teaching, Learning and Assessing science, 5-12. London: Paul Chapman.

[26] Harrison, C. (1999). Visual representation of the young gifted child. Roeper Review, 21(3), 189-194.

[27] Harrison, C. (2004). Giftedness in early childhood: The research for complexity and connection. Roper Review, 26(2), 78-84.

[28] Henderson, S. J., Jackson, N.E. \& Mukamal, R. A. (1993). Early development of language and literacy skills of an extremely precocious reader. Talented Child Quarterly, 37 (2), 78-83.

[29] Hix, B. O. (1990). The relationship between the conservation response and giftedness in first grade children: An educational field problem research project report. Unpublished master's thesis, Mercer University, Georgia.

[30] Hoh, P. (2005). The linguistic advantage of the intellectually gifted child: An empirical study of spontaneous speech. Roper Review, 27(3), 178-185.

[31] Hou, Y. L. (2009). The relationship between the gifted traits of preschool children and scientific creativity: The mediating effect of the flow experience. Bulletin of Special Education, 34(2), 101-118.

[32] Kanevsky, L. S. (1992). The learning game. In P. S. Klein \& A. J. Tannenbaum (Eds.), To be young and gifted (pp. 204-241). Norwood, NJ: Ablex.

[33] Keating, D. P. (1991). Curriculum options for the developmentally advanced: A developmental alternative to gifted education. Exceptionality Education Canada, 1, 53-83.

[34] Kim, K. H. (2005). Can only intelligent people be creative? Journal of Secondary Gifted Education, 16, 57-66.

[35] Kitano, M. (1985). Ethnography of a preschool for the gifted: What gifted young children actually do. Gifted Children Quarterly, 29, 67-71.

[36] Kontos, S. \& Wilcox-Herzog, A. (1997). Teachers' interactions with children: Why are they so important? Young Children, 52, 4-12.

[37] Kuo, C. C., Maker, J., Su, F. L., \& Hu, C. (2010). Identifying young gifted children and cultivating problem solving abilities and multiple intelligences. Learning and Individual Differences, 20(4), 365-379.
[38] Lempers, J., Block, L., Scott, M., \& Draper, D. (1987). The relationship between psychometric brightness and cognitive-developmental precocity in gifted preschoolers. Merrill-Palmer Quarterly, 33, 489-503.

[39] Linell, P. (2009). Rethinking Language, Mind, and World Dialogically. Charlotte, NC: Information Age Publishing.

[40] Louis, B., \& Lewis, M. (1992). Parental beliefs about giftedness in young children and their relation to actual ability level. Gifted Child Quarterly, 36(1), 27-31.

[41] Margrain, V. (2010). Narratives of young gifted children. Kairaranga, 11(2), 33-38.

[42] Marini, Z., \& Case, R. (1994). The development of abstract reasoning about the physical and social world. Child Development, 65, 147-159.

[43] Martin, R. (2007). The psychology of humor: An integrative approach. New York, NY: Academic Press.

[44] McGhee, P. E. (1971). Cognitive development and children's comprehension of humor. Child Development, 42, 123-138.

[45] McGhee, P. E. (1976). Children's appreciation of humor: A test of the cognitive congruency principle. Child Development, 47, 420-426.

[46] Morrissey, A. \& Brown, P. B. (2009). Mother and toddler activity in the zone of proximal development for pretend play as a predictor of higher Child IQ. Gifted Child Quarterly, 53(2), 106-120.

[47] Murdock, M. C., \& Ganim, R. M., (1993). Creativity and humor: Integration and incongruity. Journal of Creative Behavior, 27(1), 57-70.

[48] Nellis, L. M. \& Gridley, B. S. (2000). Sociocultural problem-solving skills in preschoolers of high intellectual ability. Gifted Child Quarterly, 44(1), 33-44.

[49] O'Brien, P. (2000). A challenging curriculum for the more able pupil. In J. Sears, \& P. Sorenson (Eds.), Issues in science teaching (pp.185-195). London: Routledge.

[50] O'Quin, K., \& Derks, P. (1997). Humor and creativity: A review of the empirical literature. In M. A. Runco (Ed.), The creativity handbook (Vol. 1, pp.227-256). Cresskill, NJ: Hampton Press.

[51] Piaget, J. (1964). Cognitive development in children: Development and learning. Journal of Research in Science Teaching,2, 176-186.

[52] Robinson, N. M. \& Robinson, H. (1992). The use of standardized tests with young talented children. In Klein P.S. and Tannenbaum A. J. (Eds.), To be Young and Talented. Norwood, NJ: Ablex, 141-170.

[53] Robinson, N. M. (1993). Parenting the very young gifted child. Storrs, CT: National Research Center on the Gifted and Talented. ED 371536.

[54] Robinson, N. M. (2000). Giftedness in very young children: How seriously should it be taken? In R. C. Friedman \& B. M. Shore (Eds.), Talents unfolding: Cognition and development (pp. 7-26). Washington, DC: American Psychological Association. 
[55] Scott, J. (1993). Introduction. In J. Scott (Ed.), Science and language links. Portsmouth, NH: Heinemann.

[56] Scott, M. S., \& Delgado, C. F. (2005). Identifying cognitively gifted minority students in preschool. Gifted Child Quarterly, 49, 199-210.

[57] Siry, C., Ziegler, G., \& Max, C. (2012). "Doing Science" through discourse-in-interaction: Young children's science investigations at the early childhood level. Science Education, 96(2), 311-326.

[58] Steiner, H. H. (2006). A Micro-genetic analysis of strategic variability in gifted and average-ability children. The Gifted Child Quarterly, 50(1), 62-74.

[59] Tobin, K., Tippins, D. J., \& Gallard, A. J. (1994). Research on instructional strategies for teaching science. In G. L. Gabet (Ed.), Handbook of research on science teaching and learning (pp. 45-93). NJ: Macmillan.

[60] Tucker, B., \& Hafenstein, N. L. (1997). Psychological intensities in young gifted children. Gifted Child Quarterly, 41(3), 66-75.

[61] Wergerif, R. (2011). Towards a dialogic theory of how children learn to think. Thinking Skills and Creativity, 6 , 179-190.

[62] West. A. (2000). Practical work for the gifted in science. In K. S. Taber (Ed.), Science education for gifted learners (pp.172-181). London: Routledge.

[63] Wolfe, L. F. (1989). Analyzing science lessons: A case study with gifted children. Bandura, A. (1989). Regulation of cognitive processes through perceived self-efficacy. Developmental Psychology, 25(5), 729-735. 